\title{
Impact of Advertising on Consumer Purchase Intention: A Study of Southern Punjab
}

\author{
Ansar Abbas, Irfan Ahmed Khan, Ahmed Din, Muhammad Shazaib* \\ Faculty Of Management Sciences, Department Of Commerce, Shah Abdul Latif University Khairpur Mirs \\ *Department of public administration, BZU, Multan
}

\begin{abstract}
The aim of this research was to know the impact of advertising on consumer purchase intention; the research area was south region of Pakistan. This research was based on primary data that was calculated from the respondents of south region of Pakistan through questionnaire. The correlation and regression tests were applied through SSPSS software. A significant relation was found among all the variables and model was found appropriate. This research is helpful for the policy makers, managers and related business firms.

DOI: $10.7176 / \mathrm{EJBM} / 12-19-01$
\end{abstract}

Publication date:July $31^{\text {st }} 2020$

\section{Introduction:}

\section{1:Background of Study}

Advertising could be defined as a communication tool that convey a message to promote the sale of a product or service(Roberts 1996). Advertising convey the message through different channels such as newspapers, television and radio. The present world is more cognizant about society at whatever point they settle on a buy choice. The best device that the advertisers and publicists frequently use to get consumers"e consideration is publicizing, which encourages buyers to expand their insight about item properties and particular (Buda and Zhang, 2000). Intent to buy is a sort of choice in which considered why a client buys a brand specifically. Builds like considering something acquiring a brand and envisioning to buy a brand helps to scope the expectations of obtaining (Porter, 1974). Porter (1974) additionally expounded clients' aim to buy an engaged brand isn't just by his equivalent brand attitude, yet additionally by his states of mind prompting different brands in decision of set considered. Researchers clarified a kind of loyal client, whose buying choice is insensitive to estimating and the demonstrate their truthfulness by proposing positive proposals to firm and notwithstanding putting cash in the brand which demonstrate their extraordinary trust in the brand. Porter (1974) clarified that clients purchasing conduct likewise rely upon the level of existing rivalry in the business(Bing 2012). A customer does not become loyal to a brand easily. The firm has to spend a lot to attract the customers by different promotion tools. The promotion tool on which the company spend a lot is advertising(Belch and Belch 2004). This promotion tools plays an important role to boost up the company sales and make the customer loyal. The brand lover customer are considered the people who have the purchasing power(Zhu 2012). Customers' expressed buy aims are one of the essential data sources that showcasing supervisors use to gauge future deals and to decide how the moves they make will affect buyers' acquiring conduct. Somewhere in the range of 70 and 90 percent of customers of statistical surveying providers showed in an investigation that they routinely measure and utilize purchase intentions (Jamieson and Bass, 1989. The willingness of a client to purchase a specific item or a specific administration is known as buy expectation. Buy aim is a reliant variable that relies upon a few outside and inner elements. Purchase intentions are used to measure consumer demand for new products using concept and product tests. Mental research recommends that understanding expectations of others might be an essential for a more elevated amount comprehension of other individuals' brains or hypothesis of psyche. Hypothesis of mind examine endeavors to outline kids ring a bell as an illustrative gadget for the world. This examination has concentrated on the improvement of learning that others have convictions, wants, and aims that are not quite the same as one's own(Shimp 1997). An essential capacity to fathom other individuals' goals dependent on their activities is basic to the improvement of hypothesis of psyche. Understanding expectation is believed to be vital in understanding social settings from various perspectives. To start with, obtaining a comprehension of goal is critical for advancement in that it enables kids to conceptualize how individuals and creatures vary from items. Advertising is a showcasing correspondence that utilizes a transparently supported, non-individual message to advance or offer an item, administration or thought. Backers of publicizing are normally organizations wishing to advance their items or administrations(Rossiter and Percy 1987). Promoting is separated from advertising in that a sponsor pays for and has command over the message. It varies from individual offering in that the message is non-individual, i.e., not coordinated to a specific individual. Advertising is conveyed through different broad communications, including customary media, for example, daily papers, magazines, TV, radio, open air promoting or post office based mail; and new media, for example, list items, web journals, online networking, sites or instant messages. The genuine introduction of the message in a medium is alluded to as a notice, or "promotion" or advert for short(Ramayah, Lee et al. 2010). Business promotions frequently try to create expanded utilization of their items or administrations 
through "marking", which relates an item name or picture with specific characteristics in the brains of customers. Then again, promotions that plan to evoke a prompt deal are known as immediate reaction publicizing. Nonbusiness elements that publicize more than buyer items or administrations incorporate political gatherings, intrigue gatherings, religious associations and legislative offices(Lavidge and Steiner 2000).

\section{2: Identification of Gap}

Different studies have been conducted in different areas and reported their results. The southern Punjab areas have not been included on this topic. This study will focus the market of southern Punjab to explore the impact of advertising on consumer purchase intention.

\section{3: Problem Statement}

There are several competitors in the market who are offering their product to fulfill the needs of customers. All the main competitor are bearing high marketing cost but there is not proved increase in customer purchasing so there is need to notify those basic marketing channel that affect customer purchase intention. It is proved from the appropriate review that off line marking is not sufficient to initiate purchases now a days because it is limited scope and also it is too expensive.

\section{4: Objective of Study}

Following are the main objectives of this study:

$>$ To examine the scope of two factors.

$>$ To explore the impact of advertising on consumer purchase intention.

\section{Literature Review \\ 2.1: Consumer Purchase Intention}

Consumers are known as the assets of the company either they are existing consumers or the potential consumers. The loyal consumers of the company are the source of income for a company(Ohanian 1991). The matter of the purchase intention is concern with the purchase power of the consumer as well as the need of the consumers. Some of the basic products which are necessary for living are the basic need of the customer. Purchase intention is the willingness of the consumers and in this situation the consumer is ready for the purchasing(Grewal, Krishnan et al. 1998). To make the consumer ready to buy the product there are some motives which make the consumers willing to buy the product. Advertising is one of the motives that play it role to the consumer intention. We can say that promotion plays the key role for capturing the consumer intention. So company spends huge budget for their promotional activities to capture the consumer intention to their products(Grewal, Krishnan et al. 1998). Consumer decision for purchasing the company products through this type of promotional tools or these activities to permute and increase the sale of the company. This study will help the company to promote their product by these types of promotional activities. Consumer purchase intention is the willingness of consumer which is made by different motives by different techniques(McKnight, Choudhury et al. 2002). At last, retailers are beginning to give careful consideration to their store name and are spending more to advance their name and build up a proper picture. Burns expanded their bud-get in 1996 (from \$556.3 million of every 1995 to \$588.1 million out of 1996) to help their "gentler side" battle. Hole expanded its financial plan by $72.6 \%$ to advance its name "Hole". K-Mart is overwhelmingly handling store picture and development issues through a store recharging program. As a major aspect of the store recharging program, K-Mart is attempting to make shopping simple, invigorating and even fun(Grewal, Krishnan et al. 1998). Kotler (1999) As found in the "purchasing choice process-demonstrate" above, customers has gone through five phases in purchaser purchasing choice process. Customers are not going all phases at each buy. In day by day schedule buys consumers as a rule skirt a few phases(Achrol and Kotler 1999).

\section{2: Advertising}

What is inadequate in the required "assessment" of promoting is any huge assortment of research particularly relating publicizing to states of mind, and these thus to buying conduct(Kamins, Brand et al. 1989). That is, we have had as a main priority a model of the right and successful impact process which has not yet been checked(Krugman 1965). This is the bugaboo that has been the expectation and the surrender all expectations regarding research individuals inside the business. Continuously there weaving machines well known la-la-land: If the customer will set up enough cash, in the event that he will see enough to coordinate in passing out specific urban communities or territories to allow a controlled investigation, if the urban areas or regions under examination will be effectively coordinated, if the boards of buyers to be contemplated won't liquefy away in later not at-homes, refusals, or changes of habitation, if the business information will be "spotless" enough to fill in as sufficient criteria - at that point without a doubt one can genuinely survey the effect of a specific promotion battle! A few promoters, as well, are figuring out how to get some information about this sort of assessment, while the publicizing organizations are irresolute and uncertain of their quality(Kaul and Wittink 1995). This is by all 
accounts where we are today. The monetary effect of advertising is significant and archived. Its messages have been learned by the general population. Just the absence of particular case narratives relating publicizing to states of mind to deals shields scientists from reasoning that the business utilization of the medium is a win(Kalra and Goodstein 1998). We are confronted then with the odd circumstance of realizing that promoting works however being notable say much in regards to why. Maybe our model of the impact procedure isn't right. Maybe it is not completely comprehended. In 1959 Herbert Zielske, in "The Remembering and Forgetting of Advertising," exhibited that publicizing will be immediately overlooked if not persistently exposed(Guthrie 1971). Why such requirement for steady support? Why so natural in and simple out of here and now memory? One answer is that quite a bit of publicizing content is found out as trivial hogwash material. Accordingly, given us a chance to get some information about the idea of such learning(Baker and Churchill Jr 1977). Advertising is a strategy used to draw in individuals' consideration. Publicizing is an imperative and basic methodology for organizations to make themselves known. Most adverts can be found in daily papers, magazines, announcement, transports, web, and on the radio, flyers, pamphlets or blurbs. The two best ways of promotion are TV and magazines. This is for the most part on the grounds that most of the populaces want to focus on those kinds of mechanical correspondence(Meenaghan 1995). Advertising are typically made fruitful with a comedic wind, big name appearances or coming to the heart of the matter. They are constantly made fruitful with. The organizations picked motto for that character. For instance, the Halifax advert has Howard, a now previous laborer for Halifax, singing celebrated, surely understood melodies with verses modified to suit rates and advance(MacKenzie, Lutz et al. 1986).

\section{4: Hypothesis}

H1: Advertising has significant impact on consumer purchase intention.

\section{5: Theoretical Framework}

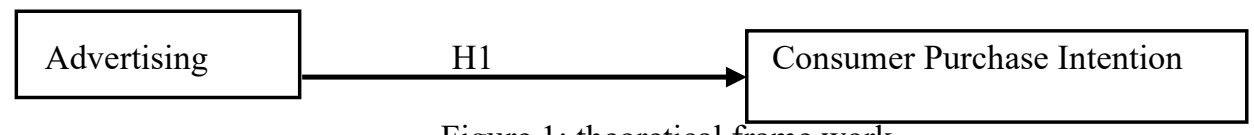

Figure 1: theoretical frame work

\section{Research Methodology}

The population of this study consists of educational sector of South Punjab. Among educational sector university students were targeted. Four universities which are Bahauddin Zakariya University, Institute of Southern Punjab, Ghazi University, and University of Education (D. G. Khan Campus) were took into consideration. The sample size of this study consists of 150 university students. Simple random sampling technique was used for primary data collection. In this sampling technique respondents have equal chance of selection from the population.

\subsection{Instrument}

Data was collected from the respondents through questionnaire. Questionnaire was used for exact and precise data. Questionnaire was adapted according to variables and keeping in mind about literature for research purpose. Questionnaire comprised of demographic section including 10 items of Advertising and Consumers Purchase Intention.

\subsection{Measurement}

Variables in this study were measured by using different scales. All questions were measured on five point Likert scale. Advertising was measured by selecting five items from the scale developed by and measured on five point likert scale. Consumers Purchase Intention was measured by selecting five items from the scale developed by(Parsons and Lepkowska-White 2009) and measured on five point Likert scale. Likert-type scale was used as (1=Strongly Disagree; 2= Disagree; 3= Neutral; 4= Agree; 5= Strongly Agree).

\subsection{Procedure}

This research selected four Universities, Bahauddin Zakariya University, Institute of Southern Punjab, Ghazi University, and University of Education (D. G. Khan Campus). Universitys' students were targeted to get responses. Researchers themselves went to students to brief them about research topic at first and then after their consent collected primary data through questionnaire. Questionnaires were filled on the spot in the presence of researchers. Targeted universities were chosen on the basis of ease to access of students.

\section{Results and Discussions}

Primary data was entered into SPSS for analyzing results. All data of Advertising and Consumers Purchase Intention was analyzed through SPSS. For analyzing data multiple tests were applied such as Reliability or 
Cronbach Alpha test, Pearson Correlation, Regression analysis mediation effect tested by using SPSS and Andrew F. Hayes process macros.

Table 1 illustrates values of Cronbach's Alpha according to (Lewandowski, Devous MD et al. 1987), if the value of Cronbach's alpha is greater than 0.7 then the instrument will be reliable. The table depicts the values of Cronbach's alpha of negative past experiences, moral violation, brand hate and negative word of mouth as .816 .776 .823 .828 respectively. Hence the instrument is reliable (Morgan, Leech et al. 2004).

\subsection{Reliability Analysis}

According to Nunnally (1987), if the value of Cronbach's alpha is greater than 0.7 then the instrument will be reliable. The table depicted that the value of cronbach's alpha of all variables greater than 0.7 , so the instrument is reliable. (Leech, Barrett, \& Morgan, 2004). The validity of questionnaire is checked by educational experts.

Table 1 Inter item consistency-Cronbach $\alpha$

\begin{tabular}{lcc}
\hline Variable name & Cronbach's Alpha & No of Items \\
\hline Advertising & 0.740 & 5 \\
Consumer Purchase Intention & 0.809 & 5 \\
\hline
\end{tabular}

4.2 Demographic Analysis Table2: Demographic Statistics

Table2: Gender

\begin{tabular}{rlrrrr}
\hline & & Frequency & Percent & Valid Percent & Cumulative Percent \\
\hline \multirow{3}{*}{ Valid } & Male & 82 & 82.0 & 82.0 & 82.0 \\
& Female & 18 & 18.0 & 18.0 & 100.0 \\
& Total & 100 & 100.0 & 100.0 & \\
\hline
\end{tabular}

Table3: Age

\begin{tabular}{rrrrrr}
\hline & \multicolumn{1}{c}{ Frequency } & Percent & Valid Percent & Cumulative Percent \\
\hline \multirow{4}{*}{ Valid } & 15 & 15.0 & 15.0 & 15.0 \\
& $18-22$ & 58 & 58.0 & 58.0 & 73.0 \\
& $27-26$ & 26 & 26.0 & 26.0 & 99.0 \\
& $31-30$ & 1 & 1.0 & 1.0 & 100.0 \\
& Total & 100 & 100.0 & 100.0 & \\
\hline
\end{tabular}

Table4: Qualification

\begin{tabular}{rlrrrr}
\hline & & Frequency & Percent & Valid Percent & Cumulative Percent \\
\hline \multirow{4}{*}{ Valid } & Graduate & 13 & 13.0 & 13.0 & 13.0 \\
& Master & 58 & 58.0 & 58.0 & 71.0 \\
& M.Phil & 24 & 24.0 & 24.0 & 95.0 \\
& Ph.D & 5 & 5.0 & 5.0 & 100.0 \\
& Total & 100 & 100.0 & 100.0 & \\
\hline
\end{tabular}

Frequency distribution tests have been used, to analyze the demographic features of data like Gender, Age and Qualification. The result of frequency distribution depicted that most of the respondents are male. The individuals aged 23-26 years showed highest overall response rate is of 58 percent. Respondents who have (Master) level of Qualification, showed higher response rate percent that is 58\%. The respondents who participated mostly don't have working experience.

\subsection{Descriptive Statistics}

Table:5 Descriptive Statistics

\begin{tabular}{|c|c|c|c|c|c|c|c|c|c|c|}
\hline & & $\mathrm{N}$ & Minimum & Maximum & Mean & $\begin{array}{c}\text { Std. } \\
\text { Deviation }\end{array}$ & \multicolumn{2}{|c|}{ Skewness } & \multicolumn{2}{|c|}{ Kurtosis } \\
\hline & & Statistic & Statistic & Statistic & Statistic & Statistic & Statistic & $\begin{array}{l}\text { Std. } \\
\text { Error }\end{array}$ & Statistic & $\begin{array}{c}\text { Std. } \\
\text { Error }\end{array}$ \\
\hline Advertising & & 100 & 2.40 & 4.40 & 3.5800 & .40151 & -.923 & .241 & .682 & .478 \\
\hline CPI & & 100 & 2.80 & 4.60 & 3.7380 & .35584 & -.363 & .241 & .637 & .478 \\
\hline $\begin{array}{l}\text { Valid } \\
\text { (listwise) }\end{array}$ & $\mathrm{N}$ & 100 & & & & & & & & \\
\hline
\end{tabular}

Descriptive statistics explained the trend and level of existence of variables. The minimum and maximum showed the correctness of data and it should be in limits of measurement scale of instruments. As shown above, 
the maximum and minimum values are in the range from 1 to 5 likert scale. No value is less than 1 and no value above then 5 for all the independent and dependent variables. The mean of two variables is greater than 3 that mean all the average of responses lies in the agreement area the values of skewness should range from -1 to +1 while kurtosis should range from -3 to +3 and this is acceptable range(Sekaran \& Bougie 2003). It is evident that all the statistics of skweness and kurtosis is within the acceptable range. So data collected for this study is normal this is also first and foremost assumption of regression analysis.

Table 6: Correlations

\begin{tabular}{llrr}
\hline & & Advertising & CPI \\
\hline \multirow{3}{*}{ Advertising } & Pearson Correlation & 1 & \\
& Sig. (2-tailed) & & \\
& $\mathrm{N}$ & $.268^{* *}$ & 100 \\
\multirow{2}{*}{$\mathrm{CPI}$} & Pearson Correlation & .007 & 1 \\
& Sig. (2-tailed) & 100 & 100 \\
\hline
\end{tabular}

**. Correlation is significant at the 0.01 level (2-tailed).

The correlation between the independent variables (Advertising) and dependent variable (consumer purchase intention) showed the value of $.393, .573, .309, .584$ and.393 respectively. If the value of Pearson correlation coefficient is between -0.3 to +0.3 then there exists a weak relationship between the variables. If the value of Pearson correlation coefficient range is 0.3-0.7 then there exists a moderate relationship. And above 0.7 shows strong relationship between variables. (Leech, Barrett, \& Morgan, 2004)Advertising have positive relationship with consumer purchase intention.

\subsection{Regression Analysis}

Table:7 Variables Entered/Removed ${ }^{\text {a }}$

\begin{tabular}{|c|c|c|}
\hline Model & Variables Entered & Variables Removed \\
\hline 1 & Advertising ${ }^{\mathrm{b}}$ & Enter \\
\hline
\end{tabular}

a. Dependent Variable: CPI

b. All requested variables entered.

Table8: Model Summary ${ }^{b}$

\begin{tabular}{lrrrrr}
\hline Model & R & R Square & Adjusted R Square & $\begin{array}{c}\text { Std. Error of the } \\
\text { Estimate }\end{array}$ & Durbin-Watson \\
\hline 1 & $.268^{\mathrm{a}}$ & .072 & .063 & .34453 & 1.821 \\
\hline
\end{tabular}

a. Predictors: (Constant), Advertising

b. Dependent Variable: CPI

Table9: ANOVA ${ }^{a}$

\begin{tabular}{|c|c|c|c|c|c|c|}
\hline Model & & Sum of Squares & $\mathrm{df}$ & Mean Square & $\mathrm{F}$ & Sig. \\
\hline \multirow{3}{*}{1} & Regression & .903 & 1 & .903 & 7.606 & $.007^{\mathrm{b}}$ \\
\hline & Residual & 11.633 & 98 & .119 & & \\
\hline & Total & 12.536 & 99 & & & \\
\hline
\end{tabular}

a. Dependent Variable: CPI

b. Predictors: (Constant), Advertising

Table10: Residuals Statistics ${ }^{\mathrm{a}}$

\begin{tabular}{lrrrrr}
\hline & Minimum & \multicolumn{1}{c}{ Maximum } & \multicolumn{1}{c}{ Mean } & \multicolumn{1}{c}{ Std. Deviation } & $\mathrm{N}$ \\
\hline Predicted Value & 3.4573 & 3.9330 & 3.7380 & .09550 & 100 \\
Residual & -.99033 & .76211 & .00000 & .34279 & 100 \\
Std. Predicted Value & -2.939 & 2.042 & .000 & 1.000 & 100 \\
Std. Residual & -2.874 & 2.212 & .000 & .995 & 100 \\
\hline
\end{tabular}

a. Dependent Variable: CPI 


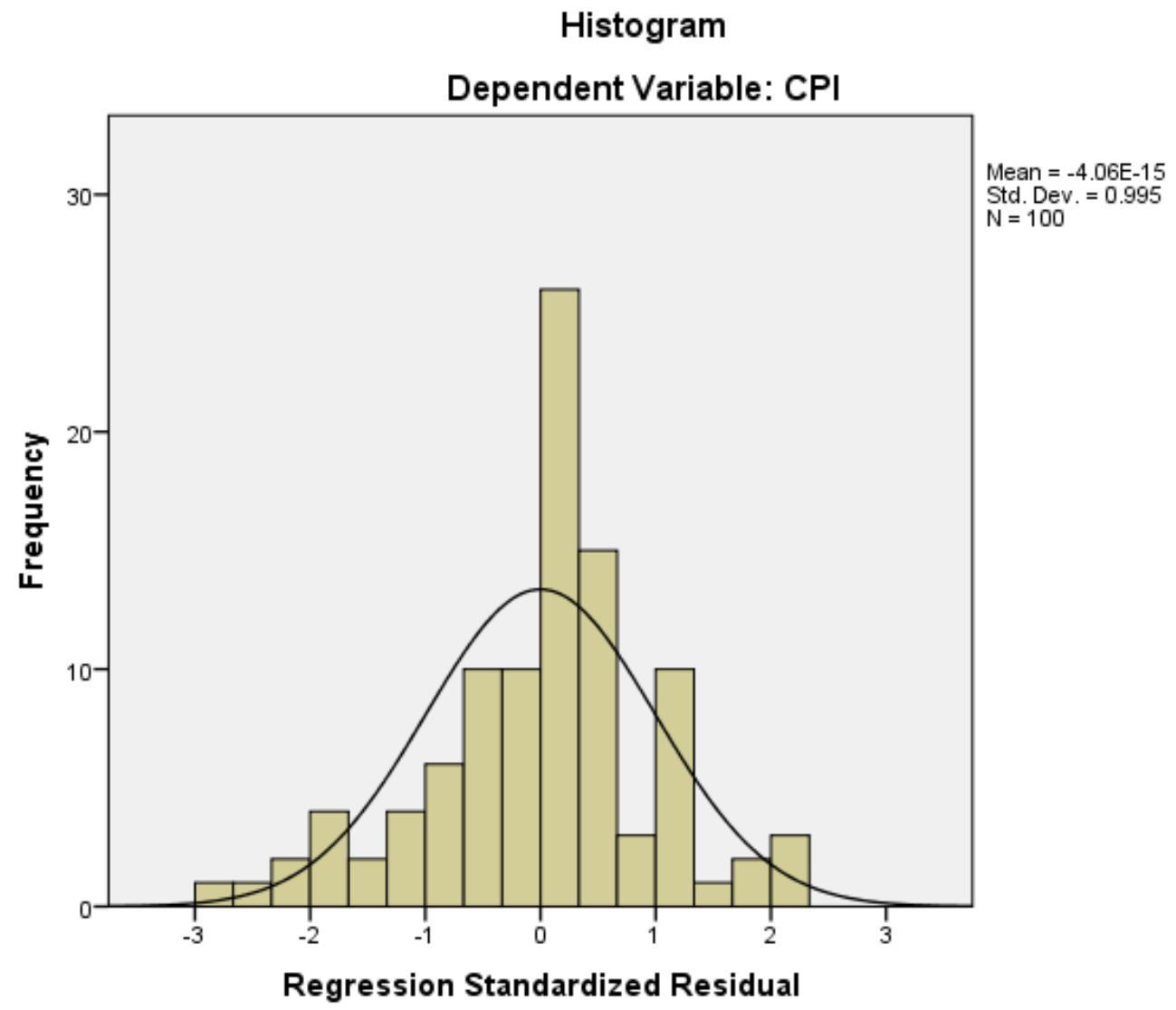

Figure2: RSD

The regression analysis showed the value of Durbin Watson is in the range. So no problem of serial correlation. The $\mathrm{R}$ showed the multiple correlation coefficients. It is the combined correlation of independent variable and dependent variable. Its value is 0.468 that depicted that all the independent variable has moderated relation with dependent variable. $\mathrm{R}^{2}$ is the explanatory power of the model. It depicted the explained variation in Dependent variable due to independent variable. The value of $R$ square is 0.428 that explained 42.8 percent variation in dependent variable (purchasing intention) due to independent variable (Advertising). It explained the variation for sample and adjusted $\mathrm{R}$ square showed the variation for population i.e. Four universities in southern punjab.

Beta is the slope of relationship. However significant value of the variable (Advertising) is less than 0.05 , so the relationship between the advertising and purchasing intention is significant. At the same time, the $t$ value is more than 2, so a hypothesis is accepted.

\subsection{Hypotheses Result Summary}

Table11: Hypotheses summary

\begin{tabular}{clc}
\hline \multicolumn{1}{c}{ Hypotheses } & \multicolumn{1}{c}{ Statement of hypotheses } & Result \\
\hline Hypothesis 1 (H1) & $\begin{array}{l}\text { Impact of advertising on Consumer Purchase } \\
\text { Intention }\end{array}$ & Accepted \\
\hline
\end{tabular}

\subsection{Discussion and Analysis}

\section{Hypothesis 1}

From this study it is concluded that there is significant relation exist in advertising and consumer purchase intention.

\section{Conclusion}

This study highlights that what are the factors that make advertising more appealing to readers regarding product purchase. People interact with each other and ask different opinions about products and services, discuss pros and cons about it, rely onto each other's suggestions and alter their purchase intention according to it. There are different factors that are affecting these online interactions among current and potential consumers and making advertising more persuasive that ultimately shapes consumer purchase intention. This study concludes that consumer marketing like engaging current and potential consumers on TV advertising communities and social networking sites and educating consumers about product will help companies to increase their product awareness. 
This study concludes that within Pakistan people do not see quality information, social tie as a impactful factors that make advertising more persuasive because they perceive that most of the time information given on advertisement is fabricated and having a relationship with someone doesn't impact either to make appealing. Also social ties even don't matter much in Pakistani context like people think that their purchase intention is not going to be influenced only on the basis of information provide by their family and friends because their needs might be different hence purchasing intention is not going to be effected. Although advertisement affects purchase intention therefore for managers of companies should put effort to increase the advertisement but it doesn't mean that advertisement generated will help them to influence people to buy and increase their company sales. Mean while marketers of companies can design such a campaign in which discussions are taking place on large extent where numbers of participants are large and where numbers of comments generated are more. This large discussion on the basis of content and comments generated will attract people and it will persuade people to make positive purchase intention.

\subsection{Limitations}

The data for this study is gathered from the Pakistani university students from the South Punjab area. So these findings cannot be generalized the whole country. The current study is of cross sectional nature. Longitudinal studies are trending nowadays. It's a prerequisite for longitudinal studies that data is been collected over different time intervals but due to time constraint it was difficult to conduct a longitudinal analysis of variables under study. This study has been conducted in the Pakistani context so considering cultural aspects this study is limited in its findings.

\section{Suggestions for Future Research}

Future directions for researchers can be that current study has investigated the role of mediation between the independent and dependent variables. It is recommended that the role of moderator should be studied between independent and dependent variable. More factors should also be made part of study to get a clearer picture. Current study has investigated this model for only university students of South Punjab region. It is suggested that further research should be tested for university student or some other provinces can be included to expand the horizon of knowledge. Current study is based on cross-sectional research. For seeking better knowledge of the current model it is suggested to test it with longitudinal research to get better results.

\section{References:}

Achrol, R. S. and P. Kotler (1999). "Marketing in the network economy." The Journal of Marketing: 146-163.

Baker, M. J. and G. A. Churchill Jr (1977). "The impact of physically attractive models on advertising evaluations." Journal of Marketing Research: 538-555.

Belch, G. E. and M. A. Belch (2004). Advertising and Promotion: An Integrated Marketing Communications Perspective 6th, New York: NY: McGraw-Hill.

Bing, Z. (2012). "The Impact of Green Advertising on Consumer Purchase Intention of Green Products."

Grewal, D., et al. (1998). "The effect of store name, brand name and price discounts on consumers' evaluations and purchase intentions." Journal of retailing 74(3): 331-352.

Guthrie, R. V. (1971). Psychology in the World Today: An Interdisciplinary Approach, Addison-Wesley Publishing Company.

Kalra, A. and R. C. Goodstein (1998). "The impact of advertising positioning strategies on consumer price sensitivity." Journal of Marketing Research: 210-224.

Kamins, M. A., et al. (1989). "Two-sided versus one-sided celebrity endorsements: The impact on advertising effectiveness and credibility." Journal of advertising 18(2): 4-10.

Kaul, A. and D. R. Wittink (1995). "Empirical generalizations about the impact of advertising on price sensitivity and price." Marketing Science 14(3_supplement): G151-G160.

Krugman, H. E. (1965). "The impact of television advertising: Learning without involvement." Public opinion quarterly 29(3): 349-356.

Lavidge, R. J. and G. A. Steiner (2000). "A model for predictive measurements of advertising effectiveness." Advertising \& Society Review 1(1).

Lewandowski, E., et al. (1987). "High-energy phosphates and function in isolated, working rabbit hearts." American Journal of Physiology-Heart and Circulatory Physiology 253(5): H1215-H1223.

MacKenzie, S. B., et al. (1986). "The role of attitude toward the ad as a mediator of advertising effectiveness: A test of competing explanations." Journal of Marketing Research: 130-143.

McKnight, D. H., et al. (2002). "The impact of initial consumer trust on intentions to transact with a web site: a trust building model." The journal of strategic information systems 11(3-4): 297-323.

Meenaghan, T. (1995). "The role of advertising in brand image development." Journal of product \& brand management 4(4): 23-34. 
Morgan, G. A., et al. (2004). SPSS for introductory statistics: Use and interpretation, Psychology Press.

Ohanian, R. (1991). "The impact of celebrity spokespersons' perceived image on consumers' intention to purchase." Journal of advertising Research.

Parsons, A. L. and E. Lepkowska-White (2009). "Group projects using clients versus not using clients: Do students perceive any differences?" Journal of Marketing Education 31(2): 154-159.

Ramayah, T., et al. (2010). "Green product purchase intention: Some insights from a developing country." Resources, Conservation and Recycling 54(12): 1419-1427.

Roberts, J. A. (1996). "Green consumers in the 1990s: profile and implications for advertising." Journal of business research 36(3): 217-231.

Rossiter, J. R. and L. Percy (1987). Advertising and promotion management, McGraw-Hill Book Company.

Shimp, T. A. (1997). Advertising, promotion, and supplemental aspects of integrated marketing communications, Harcourt Brace College Publishers.

Zhu, B. (2012). "The impact of green advertising on consumer purchase intention of green products." 